Article

\title{
Critical Habitat Elements, with an Emphasis on Coarse Woody Debris, Associated with Ant Presence or Absence in the Moist Cold Sub-Boreal Forests of the Interior of British Columbia
}

\author{
Robert J. Higgins ${ }^{1,2, *}$, Michael G. Gillingham ${ }^{2}$ and B. Staffan Lindgren ${ }^{2}$ \\ 1 Department of Biological Sciences, Thompson Rivers University, Kamloops, BC V2C 0C8, Canada \\ 2 Natural Resources and Environmental Sciences Institute, University of Northern British Columbia, \\ Prince George, BC V2N 4Z9, Canada; Michael.Gillingham@unbc.ca (M.G.G.); lindgren@unbc.ca (B.S.L.) \\ * Correspondence: rhiggins@tru.ca; Tel.: +1-250-828-5452
}

Academic Editor: Yowhan Son

Received: 28 March 2017; Accepted: 17 April 2017; Published: 20 April 2017

\begin{abstract}
Given both the ubiquity and ecological roles described for ants in British Columbia, an understanding of the habitat elements critical to predicting their presence is desirable. We used logistic regression to model the presence and absence of ants in sub-boreal lodgepole pine (Pinus contorta var. latifolia Engelm. ex S. Watson) forests of west-central British Columbia (BC). Methodological emphasis was placed on the association between ants and coarse woody debris (CWD) because of a high degree of utilization of this resource for nesting. Five species of ants, Camponotus herculeanus (L.), Formica aserva Forel, F. neorufibarbis Emery, Leptothorax muscorum (Nylander), and Myrmica alaskensis Wheeler, comprised approximately $90 \%$ of all captures in samples of CWD within five seral ages (2-3, 8-10, 13-15, 23-25 years post-harvest, and non-harvested stands). Seral age, presence of other ant colonies of the same species, decay class of CWD, its surface area, and whether the wood was downed woody debris (DWD) or a stump, were significant variables affecting ant presence or absence. These results are explained in the context of ant species autecology as it relates to living in cool climates.
\end{abstract}

Keywords: coarse woody debris; ants; succession; sub-boreal forests; Formicidae

\section{Introduction}

Predicting the presence or absence of species within their geographic range has been of interest to biologists for many years [1,2]. In particular, presence-absence models are important to conservation biologists attempting to define critical habitat elements necessary for species protection $[3,4]$ and increasingly, to identify habitats that may be open to the introduction of invasive species $[5,6]$. Such models are also of use to ecologists attempting to define the ecological niche of poorly understood species or species assemblages.

Despite the ubiquity of ants in Canadian forests, and their linkage to many ecosystem processes [7-9], there has been no attempt to define habitat requirements through presence-absence modelling. Ecological work on the boreal ant fauna in Fennoscandia has been more extensive, but has been largely focused on ecological factors shaping community structure. For example, changes in ant community structure with seral advancement have been described [10-12], as well as adaptations to enhance ant survival in cool coniferous forests $[13,14]$. The effects of intra-taxon competition on community structure have also been investigated $[15,16]$. Unfortunately, no direct consideration has been given to what elements in the habitat are required for the ant community itself.

Defining the critical habitat elements required by ants in Canadian forests is crucial because of the many documented roles that ants play in other ecosystems. In addition to natural landscape pest 
control [17-19], ants play an important role in soil-nutrient turnover [20], seed dispersal [7,21], grain consumption [22], and decomposition of organic material [23]. Ants are also an important food source for birds [24,25] and large omnivorous vertebrates such as black bears (Ursus americanus (Pallas)) [26] and grizzly bears (Ursus arctos L.) [27,28].

A dependence of ants upon coarse woody debris (CWD) was demonstrated by one study that identified 12 of 19 species near Prince George, in central British Columbia (BC), using woody debris as a nesting medium [29]. In a study conducted in the boreal forests of Quebec, nests of two species of ants (Camponotus herculeanus (L.) and Leptothorax canadensis Francoeur) that are also native to BC were exclusively found within CWD while nests of seven of 11 other ant species were associated with CWD at varying frequency [30]. This apparent high rate of use makes CWD a prime candidate for closer examination in the context of its associations with ants. The purpose of this study, therefore, was to identify the critical habitat elements, with emphasis upon CWD, here separated into stumps and downed woody debris (DWD), that affect ant presence-absence across five seral ages in sub-boreal lodgepole pine (Pinus contorta var. latifolia Engelm. ex S. Watson) forests of the west-central interior of BC. Through this we hope to be able to determine if a particular characteristic associated with CWD is of significant utility to the ant fauna. This may assist forest managers in setting post-harvest CWD targets for biodiversity retention.

\section{Materials and Methods}

We used records from Houston Forest Products (HFP) (Houston, BC) to identify non-harvested and post-harvested sites (seral ages: 2-3, 8-10, 13-15, 23-25 years) in lodgepole pine-leading stands within the sub-boreal spruce biogeoclimatic zone and moist-cold subzone, variant 2 (SBSmc2) [31]. All post-harvest sites had been replanted by HFP with lodgepole pine because of the commercial potential of this species in the area. We identified a minimum of three replicate sites from each seral age within a $100-\mathrm{km}$ radius of Houston, $\mathrm{BC}\left(54^{\circ} 24^{\prime} \mathrm{N}, 126^{\circ} 40^{\prime} \mathrm{W}\right)$. For non-harvested sites and 8-10 years post-harvest sites, four replicate sites were established. Replicate sites varied in distance from 5-100 km from each other. We then positioned a 1-ha sampling plot within each site so that contact with natural or artificial boundaries (e.g., streams, roads, slopes) was minimized. The plots were reference-flagged as a Cartesian $\mathrm{x}$, y grid with 25-m spacing. Sampling locations were determined using random $\mathrm{x}, \mathrm{y}$ numbers and then paced off from the nearest flagged reference point.

This study was conducted between 2003 and 2005 with all sampling for ants occurring between late June and mid-August. Non-harvested plots and 8-10 years post-harvest plots were sampled in 2003, 13-15 and 23-25 years post-harvest plots in 2004, and 2-3 years post-harvest plots in 2005. Sampling consisted of hand-sampling of strip plots for CWD. Coarse woody debris was comprised of both DWD and stumps. Downed woody debris was defined as pieces of downed wood of any length with a large end diameter $\geq 10 \mathrm{~cm}$. The threshold for inclusion of a stump was a cut end diameter of $10 \mathrm{~cm}$. As harvested blocks were clear-cut, few snags persisted overall and none were located within replicate study areas. Thus, all stumps were cut during harvesting rather than existing as naturally broken snags. Some stumps had been dislodged by heavy equipment and were resting elevated on their root mass, but these were uncommon. Some DWD were elevated by other pieces of woody debris, but these were not recorded. Almost all woody debris was created by harvesting. Downed woody debris and stumps were sampled within two $4 \times 100$-m strip transects within each 1-ha sampling plot. Each strip consisted of two $4 \times 50$-m sub-strips positioned at right angles to each other and sharing a 10-m offset center to avoid overlaps between strips. The center point was randomly positioned within the 1-ha plot, but the $4 \times 50$-m strips were allowed to extend beyond the boundaries of the plot.

Within each sampling strip, we opened CWD by hand and/or hatchet to locate and sample ant colonies. Ants were placed in 1.5-mL plastic snap-cap vials containing 95\% ethanol for later identification in the laboratory. If possible, we collected at least five individuals from each colony. Data within each strip were recorded by $4 \times 12.5-\mathrm{m}$ subsections $\left(50 \mathrm{~m}^{2}\right)$, which were used as sampling units for the purpose of analysis. We assessed all pieces of DWD within the strip, regardless of ant 
presence or absence, for large-end diameter, large-end diameter at strip boundary, small-end diameter at strip boundary, length in strip, total length, percentage bark, and the decay class of the sapwood and heartwood [32]. Equivalent measurements were also made on stumps when the center point of the stump was located within the sampling strip.

We used logistic regression to relate ant presence or absence to site variables. After assessing potential independent variables for correlations, we used backwards stepwise logistic regression (logit; STATA 9.2 2007) to identify the best models—no earlier studies existed to allow for a priori selection of potential model variables. Initial categorical variables included: nesting location (downed woody debris or stumps); seral age class (1-5), and decay class (1-5). Categorical variables were input using deviation coding. Candidate continuous variables included: large-end diameter; length (height for stumps); piece surface area; surface area of all woody debris within $50-\mathrm{m}^{2}$ sample; percentage bark; number of colonies of the same species of ant within same piece of wood; number of colonies of same species of ant within $50-\mathrm{m}^{2}$ sample; number of colonies of other species of ant within the same piece of wood; number of colonies of other species of ant within the $50-\mathrm{m}^{2}$ sample. Where correlations exceeded 0.5 only one parameter was chosen for inclusion in the initial model. In addition, we dropped specific categorical classes if that class contained less than four data points to avoid near-complete separation (Table 1; [33]). Only parameters with $p<0.05$ were maintained in final models. A post-hoc analysis for co-linearity was performed on the final model parameters to ensure no tolerance values were $<0.2$. We assessed the accuracy of each final model by its Receiver Operating Characteristic (ROC) area under the curve (AUC) score following Swets [34], given that the sampling methodology would be expected to have a high accuracy in measuring presence/absence.

We followed ant species nomenclature as revised by Bolton et al. [35] except where more recent revisions have been made. We identified ants to species using the keys of Wheeler and Wheeler [36,37] Francoeur [38], Naumann et al. [39], and Hansen and Klotz [40]. Ants of the genus Myrmica were identified using an unpublished key provided by A. Francoeur (Centre de données sur la biodiversité du Québec, Chicoutimi, Québec, Canada).

\section{Results}

Fourteen species of ants were identified from the CWD sampling in this study, while no species were incidentally observed to be nesting directly in the soil within study plots [41]. Of these, five species (Camponotus herculeanus, Formica aserva Forel, F. neorufibarbis Emery, Leptothorax muscorum (Nylander), and Myrmica alaskensis Wheeler) represented $>90 \%$ of all identifications. As a consequence, these species will be the focus of the results and discussion reported here.

The models developed for each of the five most common species as well as for all five species collectively fit the data well (ROC AUC score between 0.75 and 0.9 (Table 1), except for the F. neorufibarbis model, which had a ROC score of 0.72 [34]). Several patterns across species were evident from the logistic regression models. The first was the strong response to seral age. Ant colonies (all species pooled) were more common in seral ages 8-10,13-15, and 23-25 years post-harvest, with the greatest abundance in 13-15 years post-harvest plots $(\beta=1.63, p<0.001)$. Colonies were least abundant in both $2-3$ years post-harvest plots $(\beta=-1.48, p<0.001)$ and non-harvested plots $(\beta=-1.93$, $p<0.001)$. Only 16 colonies of ants representing two species were identified in non-harvested plots (Table 2). The extent to which each species increased or decreased in colony numbers varied with each seral change although most, F. neorufibarbis excepted, followed the pattern noted above. 
Table 1. Parameter coefficients ( $\beta$ with standard error in parentheses; odd ratios in square brackets) obtained from backwards stepwise logistic regression for five species of ants and all ants collectively.

\begin{tabular}{|c|c|c|c|c|c|c|}
\hline Model Parameter & All Ants & CAHER & FOASE & FONEO & LECAN & MYALA \\
\hline \multicolumn{7}{|l|}{ Nest Location } \\
\hline Downed Woody Debris & $-0.15(0.05) p=0.006$ & & $-0.83(0.16) p<0.001$ & & & $-0.29(0.08) p<0.001$ \\
\hline Stumps & $0.15(0.05) p=0.006$ & & $0.83(0.16) p<0.001$ & & & $0.29(0.08) p<0.001$ \\
\hline CWD surface area of piece $\left(\mathrm{m}^{2}\right)$. & $0.25(0.12)[1.28] p=0.038$ & $0.79(0.19)[2.2] p<0.001$ & $0.73(0.28)[2.08] p=0.008$ & & $0.63(0.15)[1.89] p<0.001$ & \\
\hline CWD surface area within $50-\mathrm{m}^{2}$ sample $\left(\mathrm{m}^{2}\right)$ & & & & & $-0.05(0.02)[0.95] p=0.02$ & $-1.11(0.04)[0.89] p=0.002$ \\
\hline Other ant colonies of the same species within $50-\mathrm{m}^{2}$ sub-section & a & $0.87(0.10)[0.39] p<0.001$ & $1.11(0.14)[3.03] p<0.001$ & $0.84(0.11)[2.31] p<0.001$ & $0.17(0.02)[1.19] p<0.001$ & $0.44(0.03)[1.55] p<0.001$ \\
\hline Other colonies of different species with $50-\mathrm{m}^{2}$ sub-section & a & $-0.05(0.03)[0.95] p=0.04$ & $-0.89(0.25)[0.41] p<0.001$ & & & \\
\hline $\begin{array}{l}\text { Other colonies of different species in same piece of CWD } \\
\text { Percentage Bark (\%) }\end{array}$ & a & & $-0.93(0.24)[0.41] p<0.001$ & & $-0.26(0.11)[0.77] p=0.02$ & $\begin{array}{l}-0.41(0.13)[0.66] p=0.002 \\
0.01(0.00)[1.01] p=0.4\end{array}$ \\
\hline \multicolumn{7}{|l|}{ Coarse Woody Debris } \\
\hline Decay Class 2 & $-0.38(0.08) p<0.001$ & & $-0.79(0.22) p<0.001$ & & & $-0.51(0.13) p<0.001$ \\
\hline Decay Class 3 & $0.20(0.08) p<0.001$ & & $0.10(0.21) p<0.001$ & & & $0.15(0.11) p<0.001$ \\
\hline Decay Class 4 & $0.18(0.12) p=0.13$ & & $0.69(0.30) p=0.02$ & & & $0.36(0.16) p=0.02$ \\
\hline \multicolumn{7}{|l|}{ Seral Age Class } \\
\hline Seral Age 1 ( $2-3$ years post-harvest) & $-1.48(0.16) p<0.001$ & $-1.02(0.35) p=0.003$ & $\mathrm{~b}$ & $\mathrm{~b}$ & $-1.41(0.21) p<0.001$ & $-1.43(0.35) p=0.01$ \\
\hline Seral Age 2 (8-10 years post-harvest) & $1.19(0.10) p<0.001$ & $-0.26(0.22) p=0.24$ & & & $0.33(0.11) p=0.003$ & $0.04(0.17) p=0.80$ \\
\hline Seral Age 3 (13-15 years post-harvest) & $1.63(0.11) p<0.001$ & $0.56(0.24) p=0.02$ & & & $0.88(0.11) p<0.000$ & $0.06(0.18) p=0.70$ \\
\hline Seral Age 4 (23-25 years post-harvest) & $0.63(0.12) p<0.001$ & $0.72(0.22) p=0.001$ & $\mathrm{~b}$ & & $0.20(0.15) p=0.17$ & $1.04(0.18) p<0.001$ \\
\hline Seral Age 5 (Non-harvested) & $-1.97(0.24) p<0.001$ & b & $\mathrm{b}$ & $\mathrm{b}$ & & $0.27(0.25) p=0.27$ \\
\hline Receiver Operating Characteristic & 0.79 & 0.81 & 0.86 & 0.72 & 0.78 & 0.88 \\
\hline
\end{tabular}

Data derived from coarse woody debris (CWD) sampling of five seral ages (2-3, 8-10, 13-15, 23-25 years post-harvest and non-harvested forest) of sub-boreal forest in west-central British Columbia from 2003-2005. Each model differs from the constant only model with $p<0.001$. Deviation coding was used for categorical variables. CAHER: Camponotus herculeanus; FOASE: Formica aserva; FONEO: Formica neorufibarbis; LECAN: Leptothorax muscorum; MYALA: Myrmica alaskensis. a: These parameters were not applicable in this model and were not included. b: These specific data have too few of the species to make a solution reliable [34]. 
Table 2. Number of colonies of five species of ants identified as nesting within coarse woody debris across five seral ages of sub-boreal forest in west-central British Columbia from 2003-2005.

\begin{tabular}{ccccccc}
\hline \multirow{2}{*}{ Ant Species } & & \multicolumn{5}{c}{ Seral Age (year) } \\
\cline { 3 - 7 } & & $\mathbf{2 - 3}$ & $\mathbf{8 - 1 0}$ & $\mathbf{1 3 - 1 5}$ & $\mathbf{2 3 - 2 5}$ & Non-Harvested \\
\hline \multirow{2}{*}{ Camponotus herculeanus } & absent & 467 & 736 & 545 & 279 & 298 \\
& present & $6(1.3)$ & $20(2.6)$ & $24(4.2)$ & $13(4.3)$ & $0(0)$ \\
\hline \multirow{2}{*}{ Formica aserva } & absent & 473 & 730 & 540 & 301 & 298 \\
& present & $0(0)$ & $26(3.4)$ & $29(5.1)$ & $1(0.3)$ & $0(0)$ \\
\hline \multirow{2}{*}{ Formica neorufibarbis } & absent & 470 & 709 & 566 & 292 & 298 \\
& present & $3(0.6)$ & $47(6.2)$ & $3(0.5)$ & $10(3.3)$ & $0(0)$ \\
\hline \multirow{2}{*}{ Leptothorax muscorum } & absent & 456 & 537 & 387 & 277 & 297 \\
& present & $17(3.6)$ & $219(29.0)$ & $182(32.0)$ & $25(8.3)$ & $1(0.3)$ \\
\hline \multirow{2}{*}{ Myrmica alaskensis } & absent & 467 & 687 & 434 & 228 & 283 \\
& present & $6(1.3)$ & $69(9.1)$ & $135(23.7)$ & $74(24.5)$ & $15(5.0)$ \\
\hline
\end{tabular}

Where fewer than four data points were available for a species in a given seral age, those data were excluded from the logistic model (Table 1) to avoid model errors associated with near-complete separation. Percentage present in brackets.

Three species (C. herculeanus, L. muscorum, F. aserva) responded positively to pieces of wood with a larger surface area (Table 1). There was a $120 \%$ increase in the odds of finding $C$. herculeanus in pieces of wood with each increase in surface area of $1 \mathrm{~m}^{2}(p<0.001)$ and a $108 \%$ increase for F. aserva $(p=0.008)$. Finally, two species (F. aserva, M. alaskensis) were both more likely to be found in stumps than in downed woody debris and found in wood of decay class 3 or 4 as compared to decay class 2 (Table 3), despite the abundance of wood in decay class 2 (Figure 1). Only one parameter that was included in the initial full models failed to show significance $(p \leq 0.05)$ for any species. This was the number of colonies of the same species within the same piece of wood.

The relationship between the presence of other colonies of the same species within the $50-\mathrm{m}^{2}$ sample in which the colony was identified (Table 1) was significant. The odds of finding a member of a particular species always increased if other members of that species were present within the sample. This varied from a response for L. muscorum of $19 \%$ (i.e., an odds ratio of 1.19$)$ increase $(p<0.001)$ in the odds of finding this species for each colony already located, to over $300 \%$ for $F$. aserva $(p<0.001)$.

Table 3. Number of colonies of five species of ants identified as nesting within five decay classes of coarse woody debris [32].

\begin{tabular}{ccccccc}
\hline \multirow{2}{*}{ Ant Species } & & \multicolumn{5}{c}{ Decay Class } \\
\cline { 3 - 7 } & & $\mathbf{1}$ & $\mathbf{2}$ & $\mathbf{3}$ & $\mathbf{4}$ & $\mathbf{5}$ \\
\hline \multirow{2}{*}{ Camponotus herculeanus } & absent & 31 & 1258 & 815 & 192 & 8 \\
& present & $0(0)$ & $20(1.6)$ & $32(3.8)$ & $7(3.5)$ & $0(0)$ \\
\hline \multirow{2}{*}{ Formica aserva } & absent & 31 & 1260 & 815 & 194 & 8 \\
& present & $0(0)$ & $18(1.4)$ & $32(3.8)$ & $5(2.5)$ & $0(0)$ \\
\hline \multirow{2}{*}{ Formica neorufibarbis } & absent & 31 & 1248 & 826 & 192 & 7 \\
& present & $0(0)$ & $30(2.3)$ & $21(2.5)$ & $7(3.5)$ & $1(12.5)$ \\
\hline \multirow{2}{*}{ Leptothorax muscorum } & absent & 31 & 1018 & 687 & 183 & 7 \\
& present & $0(0)$ & $260(20.3)$ & $160(18.9)$ & $16(8.0)$ & $1(12.5)$ \\
\hline \multirow{2}{*}{ Myrmica alaskensis } & absent & 31 & 1182 & 699 & 152 & 6 \\
& present & $0(0)$ & $96(7.5)$ & $148(17.5)$ & $47(2.4)$ & $2(22.2)$ \\
\hline
\end{tabular}

Sampling occurred across five seral ages of sub-boreal forest in west-central British Columbia from 2003-2005. Note: 35 pieces of CWD were lacking decay class data. Where fewer than four data points were available for a species in a given decay class, those data were excluded from the logistic model (Table 1) to avoid model errors associated with near-complete separation. Percent present in brackets. 
This pattern, however, was reversed for two species (C. herculeanus and F. aserva) when considering the presence of other species within the $50-\mathrm{m}^{2}$ sampling unit (Table 1). There was a $5 \%$ reduction in the odds of finding C. herculeanus for each colony of another species identified, but a stronger $59 \%$ reduction for $F$. aserva. When the spatial scale was reduced to the same piece of wood, three species, F. aserva, L. muscorum, and M. alaskensis, showed a decrease in the odds of their presence with each identification of another species. For example, there were $34 \%$ lower odds $(p=0.002)$ of finding a colony of M. alaskensis in a piece of wood for each colony of another species also located in that wood.

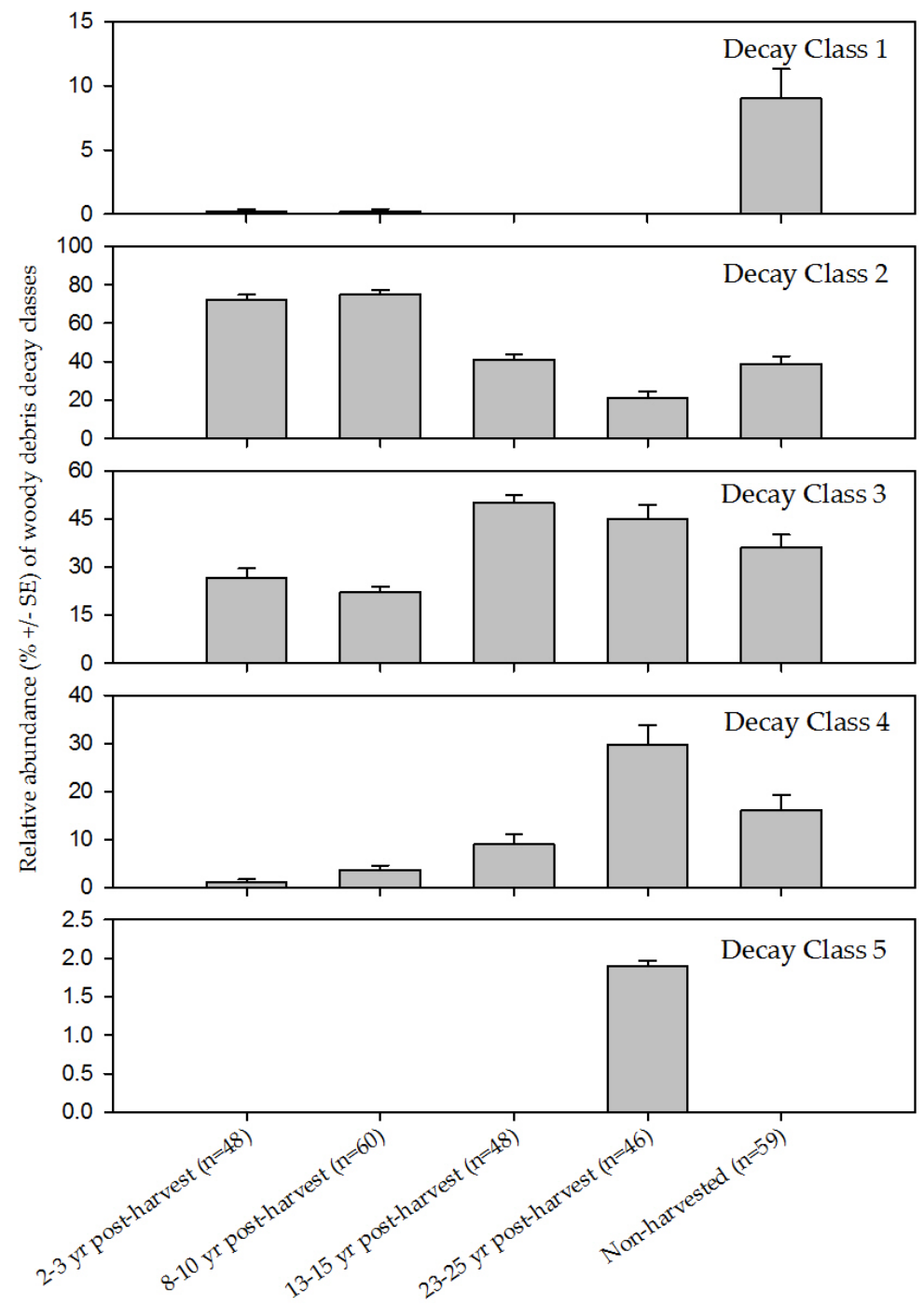

Figure 1. The mean relative distribution of decay classes [32] in 50- $\mathrm{m}^{2}$ samples for coarse woody debris and stumps from five seral ages in the moist cold sub-boreal (SBSmc2) forests of the west-central interior of British Columbia. Note that the Y-axis varies in scale. Samples collected from 2003-2005.

\section{Discussion}

The major objective of this study was to determine what environmental attributes, with an emphasis on woody debris, were significant in determining ant presence or absence. Coarse Woody Debris (CWD) appears to be a vital resource for ants in the sub-boreal forests of BC, as almost all ants in this study appear to depend upon it as a nesting resource. Although the focus of this study was ants nesting directly within CWD, no ants were incidentally observed nesting directly within the soil within sample strip-plots. Pitfall trapping and mini-Winkler litter extractions performed in 
a study related to the one reported here and in the same location, turned up only a single species (Myrmica fracticornis Forel) that was not found nesting in CWD [41]. It is possible though that this species was using CWD below our minimum size criterion $(10 \mathrm{~cm})$. Furthermore, at the peak of ant colony abundance (seral age 13-15 years), it was observed that the majority of pieces of CWD were hosting ants (Table 2).

Accurate modelling of presence-absence has traditionally been considered difficult because of uncertainty in the veracity of absence data [2,42], especially when modelling highly mobile vertebrate distributions. The solution has traditionally been to resample habitat to develop probabilities of absence [3]. In the case of social insects such as ants, however, the ability to locate and accurately identify largely stationary colonies [43], especially when they are nesting in a readily identifiable substrate such as CWD, should reduce the risk associated with single sampling methodologies and make dichotomous modeling techniques such as logistic regression appropriate.

A strong feature emerging from the regressions (Table 1) was the effect of seral age on three (C. herculeanus, M. alaskensis, and L. muscorum) of the five common species in this study. Formica neorufibarbis and F. aserva will be discussed later, as they are the exceptions here, possibly because of their interdependence. We consider seral age as a proxy for temperature (see [41]) through the decreased insolation associated with a developing forest canopy, and consider it one of the most important variables affecting the presence or absence of ants in these forests. Ant communities, overall, build through the first three seral ages (Table 2) where mean litter temperatures between June and August were reported as ranging from approximately $12-14{ }^{\circ} \mathrm{C}$ [41]. As seral age progressed beyond this, the ant community began to decline. Non-harvested sites, where mean daily temperatures between June and August were below $10{ }^{\circ} \mathrm{C}$ [41], hosted virtually no ant colonies, suggesting that temperature appears to be the most powerful force shaping overall ant presence or absence.

Models were limited on occasion by complete or near complete separation of data. The complete or near absence of ants in specific seral ages (Table 2) confounds logistic analysis, requiring that some seral ages be dropped for some species [33]. For example, F. aserva was completely absent in 2-3 years post-harvest sites, increasingly common until reaching 13-15 years post-harvest sites, and then reduced to only one record in 23-25 years post-harvest sites (Table 2). Despite the rise and sudden decline with seral age, these comparisons had to be dropped from the models, making it appear that seral age was not an important variable for this species. Subjectively, however, when considering all evidence, one can deduce that 2-3 years post-harvest plots are devoid of this species due to insufficient time for colony founding, whereas approaching 23-35 years, canopy closure has led to insufficient temperatures to sustain colonies of this highly thermophilic species [44]. Hence, in cool sub-boreal forests, F. aserva was restricted to older severely disturbed areas, occurring only after canopy removal.

An additional limitation that should be noted was the fact that this was a multiyear study where different seral ages were examined in different years. Given the size of the study it was not possible to carry out all surveys in a single year. However, we did not experience any notable fluctuations in climatic conditions through the study (i.e., unusually high or low precipitation, unusually high or low temperatures) or experience natural disturbances.

The physical characteristics of wood used for nesting (i.e., size, decay class, and use of downed wood debris or stumps) were not strongly selected for across all five species (Table 1). Further, wood use by F. aserva (that initiates nests through the parasitism of ants in the Formica fusca species group) may be an artifact of an initial choice by its host species, F. neorufibarbis, complicating interpretation. In general, however, where a significant selection of a given physical characteristic was evident in more than one of the species in our study, the direction of selection was consistent across other species also showing selection. For example, three species (C. herculeanus, F. aserva, and L. muscorum) as well as all species pooled, significantly selected for wood of greater surface area, but none preferred smaller pieces (Table 1). Larger pieces of wood would be ideal for larger species of ants with large colonies (e.g., C. herculeanus and F. aserva) and might offer greater temperature stability to smaller species (e.g., L. muscorum). 
Decay class classification ranged from 1 to 5 [32]. Wood in decay class 1 was considered as recently fallen with fine twigs, while decay class 5 was highly rotten wood with no structural integrity and usually moss covered. Two species (M. alaskensis and F. aserva) and all species pooled, preferred the older decay classes (i.e., decay classes 3 or 4 ), but none preferred younger (i.e., decay classes 1 or 2) (Table 1). Older decay classes should be easier to excavate for nesting. Some autecological factors may explain why some species of ants did not show a significant selection for decay class. For example, C. herculeanus is a strong excavator and may not be dependent upon softer wood for nesting. In addition, harder wood may be beneficial for this species in terms of predation avoidance by vertebrates [45]. The lack of preference demonstrated by L. muscorum might be explained by the minute size of these ants, where workers are thin and typically only $2.5-3.5 \mathrm{~mm}$ in total length. These ants are likely able to exploit tiny cavities beneath the bark or cracks in harder wood that are unavailable to other species. Leptothorax spp. are known to be pioneer species in boreal forests [11] and may be adapted to exploiting the early decay classes available following natural disturbances.

Finally, with respect to physical characteristics, some species (F. aserva and M. alaskensis) and all species pooled, selected stumps as compared to DWD. It has been found that stumps have a higher mean temperature in these forests as compared to DWD of an equivalent volume [44]. This may arise from the soil limiting nightly heat loss in the stump to the more stable temperature of soil through extensive contact with the roots. This was evidenced by stump temperatures not dipping below soil temperatures at night [44]. Downed woody debris, lacking this intimate contact, would not have a heat source to draw upon at night. As stumps are a fairly recent resource in these forests, it seems unlikely that ants could have an evolved preference, however, it is possible that the warmer temperatures may increase the success rate of colonies that accidentally chose this resource.

A feature shared across all species was the increase in the odds of finding a given species of ant if a colony of that same species has already been located within its $50-\mathrm{m}^{2}$ sampling unit (i.e., there is clustering) (Table 1). One possible explanation for this is that four of the five common species of ants in this study are known to be polygynous (i.e., colonies contain multiple queens). Polygyny has been documented in F. aserva [46], F. neorufibarbis [47-49], and is considered a general characteristic of Myrmica spp. [50], and Leptothorax spp. ants [51,52]. Species displaying this characteristic often, but not exclusively, reproduce through colony budding. Budding is a type of dependent nest founding [53], in which one or more newly mated queens, with workers, disperse by walking from their natal nest to a new nesting site [11,51].

Polygyny may arise when the dispersal of solitary queens is associated with a high mortality risk, as is reported for cool climates [54]. Solitary ants of Leptothorax spp. were shown to have a lower survival rate through the winter than those clustered in groups of 50 [52]. A selective pressure toward polygyny may be evident in an undescribed species of Leptothorax in eastern Canada (Leptothorax sp. A) [51]. It was observed that this species has many virgin queens that are wingless, making colony foundation through budding obligatory. Polygyny and subsequent budding would reduce the risk of colony extinction and allow the species employing this strategy to begin to spread within isolated suitable patches. It is important to note, however, that although budding is a dispersal option for many species of polygynous ants, it is unlikely to be exclusive, and dispersal by flight is also utilized [55].

Finding additional colonies of $C$. herculeanus was also improved when other colonies were located (Table 1), despite the fact that this species is monogynous [56], except in rare circumstances [57]. It is common, however, for this species to establish satellite colonies in which larvae and pupae may be raised, making it difficult to distinguish natal from satellite nests and giving the appearance of multiple colonies [40]. This form of polydomy may yield similar benefits to polygyny.

Although polygynous and polydomous colony expansions may be a common mode of colony spread in boreal forests, queen flights into new habitat are also common $[14,46,51]$ and the regression models may provide some information about habitat selection. Habitat selection during such flights has been little studied because of the difficulties in exactly anticipating the timing of mating flights and following queens as they disperse. In one rare study conducted in the eastern United States, it was 
determined that queens of the species Lasius neoniger Emery and Solenopsis molesta (Say) were usually capable of avoiding unsuitable habitat at the landscape element level (i.e., forest vs. meadow in that study) during their mating flights [58]. Of the thousands of mated L. neoniger queens observed in their study, only three were later found in the forest, leading to the hypothesis that a form of coarse- and fine-filter was used during the nuptial flight. It was suggested that queens landed randomly within a suitable landscape element (e.g., meadow), but once on the ground queens had to locate the best nesting site within a few meters or increase the risk of predation if they travelled any greater distance.

At the coarse scale of landscape elements, solitary queens were never located in non-harvested stands, but were frequently recorded in early seral ages (e.g., no Camponotus queens were located in strip sampling in non-harvested sites, but 18 were located in the 2-3 years post-harvest sites). This has also been noted in other studies [10,12,59]. Rare colonies of L. muscorum and M. alaskensis were located in non-harvested stands, but only where there were either small openings in the canopy or more open forest structure, indicating that some queens must disperse within this landscape element and possibly select such openings at an intermediate scale. At the intermediate $50-\mathrm{m}^{2}$ scale in post-harvest sites, odds ratios derived from wood surface area (Table 1) did not show strong selection, indicating that it either may not be an important factor or is simply the wrong scale for selection.

It was notable that one parameter that only weakly expressed overall was the effect of the presence of different species within the $50-\mathrm{m}^{2}$ sampling unit (Table 1). Camponotus herculeanus showed slight reduction ( $5 \%$ odds ratio) in the probability of cohabiting with other species at the $50-\mathrm{m}^{2}$ sampling scale and only F. aserva indicated a strong negative response (59\% odd ratio). It would be expected that there would be reduced odds of locating most ant species within the same $50-\mathrm{m}^{2}$ sampling unit of other species, if competitive exclusion was structuring the community, as has been documented in other ant communities [60-62]. This finding, in our study, would suggest that allospecific competition was not a significant factor, at least not at this scale. We suggest that this might arise from the transient environmental conditions typical in these forests. In the forest environments of our study, ants have only a few years before environmental conditions deteriorate (i.e., after 13-15 years post-harvest) and may not be able to saturate the environment to an adequate extent to begin to show competition. It should be noted, however, that exclusion was evident for three species (F. aserva, M. alaskensis, and L. muscorum) at the level of the wood itself. In all three cases, there were reduced odds of finding each species if other species were present. Thus, some competition is evident at the nesting scale. It is likely that most colonies establish in uncolonized wood and then repel allospecific arrivals.

\section{Conclusions}

Coarse woody debris is clearly a vital resource for the ant community in the sub-boreal forests of west-central BC. Although ants appear to be able to utilize a broad range of woody debris sizes and decay classes, it was clear that large pieces are preferred by many species, especially those forming larger colonies (e.g., C. herculeanus and F. aserva). Thus, the retention of larger pieces of woody debris should be a management objective, as ants are ecologically important from a number of perspectives (e.g., as food for bears [26-28] and birds [24]). Although the CWD volumes encountered in our study appear adequate for use by the ant fauna, concerns may arise from any significant reduction in post-harvest CWD volumes. Sweden, with much lower post-harvest volumes as compared to BC, has already identified over 500 woody debris dependent invertebrates that are at risk of extirpation [62]. Desire to reduce post-harvest CWD volumes, and to increase wood fiber availability to emerging bio-energy corporations, should be considered with extreme caution if we want to protect the organisms dependent upon this resource and the ecological processes to which they are fundamental. Finally, it has been shown that the presence of ants in woody debris inhibits the rate of decay [63]. Given the high utilization of woody debris by ants in these forests, there might be a role for ants in promoting carbon storage. 
Acknowledgments: We would like to thank Melissa Todd and Houston Forest Products (now West Fraser Timber Co., Ltd.) for supporting this project with staff time and material resources, as well as advocating for a partnership with the project team to develop a successful application for an industrial Natural Sciences and Engineering Research Council (NSERC) grant. This project could not have been completed without the field assistance of Deanna Danskin (University of Northern British Columbia-UNBC), David DeWit (Houston Forest Products), Honey-Marie de la Giroday (UNBC), Duncan McColl (UNBC), Laurel McDonald (UNBC), Anne McLeod (Houston Forest Products), Xiaokui (Lucy) Zhang, and Lisa Zukewich (UNBC). We also thank Joselito Arocena, William McGill, Hugues Massicotte, and James Hanula for valuable comments on an earlier version of this manuscript. Additional funding was provided by a NSERC Discovery Grant to B. Staffan Lindgren.

Author Contributions: Robert J. Higgins, Michael G. Gillingham, and B. Staffan Lindgren conceived and designed the experiments; Robert J. Higgins performed the experiments; all three authors contributed to the analysis of the experiments; B. Staffan Lindgren contributed funding toward the experiments and provided materials; Robert J. Higgins wrote the paper with editorial assistance from Michael G. Gillingham and B. Staffan Lindgren.

Conflicts of Interest: The authors declare no conflict of interest. The funding sponsors had no role in the design of the study; in the collection, analyses, or interpretation of data; in the writing of the manuscript, and in the decision to publish the results.

\section{References}

1. Steinitz, O.; Heller, J.; Tsoar, A.; Rotem, D.; Kadmon, R. Predicting regional patterns of similarity in species compositions for conservation planning. Conserv. Biol. 2005, 19, 1978-1988. [CrossRef]

2. Vojta, C.D. Old dog, new tricks: Innovations with presence-Absence information. J. Wildl. Manag. 2005, 69, 845-848. [CrossRef]

3. MacKenzie, D.I. What are the issues with presence-Absence data for wildlife managers? J. Wildl. Manag. 2005, 69, 849-860. [CrossRef]

4. Littlewood, N.A.; Young, M.R. A habitat suitability model for the narrow-headed ant, Formica exsecta, evaluated against independent data. Insect Conserv. Divers. 2008, 1, 108-113. [CrossRef]

5. Worner, S.P.; Gevrey, M. Modelling global insect pest assemblages to determine risk of invasion. J. Appl. Ecol. 2006, 43, 858-867. [CrossRef]

6. Watts, M.J.; Worner, S.P. Comparing ensemble and cascaded neural networks that combine biotic and abiotic variables to predict insect species distributions. Ecol. Inform. 2008, 3, 354-366. [CrossRef]

7. Gorb, S.N.; Gorb, E.V.; Punttila, P. Effects of redispersal of seeds by ants on the vegetation pattern in a deciduous forest: A case study. Acta Oecol. 2000, 21, 293-301. [CrossRef]

8. Nkem, J.N.; de Bruyn, L.A.L.; Grant, C.D.; Hulugalle, N.R. The impact of ant bioturbation and foraging activities on surrounding soil properties. Pedobiologia 2000, 44, 609-621. [CrossRef]

9. Risch, A.C.; Jurgensen, M.F.; Schutz, M.; Page-Dumroese, D.S. The contribution of red wood ants to soil C and $\mathrm{N}$ pools and $\mathrm{CO}_{2}$ emissions in subalpine forests. Ecology 2005, 86, 419-430. [CrossRef]

10. Punttila, P.; Haila, Y.; Pajunen, T.; Tukia, H. Colonisation of clearcut forests by ants in the southern Finnish taiga: A quantitative survey. Oikos 1991, 61, 250-262. [CrossRef]

11. Punttila, P.; Haila, Y.; Niemela, J.; Pajunen, T. 1994. Ant communites in fragments of old-growth tiaga and managed surroundings. Ann. Zool. Fennici 1994, 31, 131-144.

12. Punttila, P.; Haila, Y. Colonisation of a burned forest by ants in the southern Finnish boreal forest. Silva Fennica 1996, 60, 421-435. [CrossRef]

13. Seppä, P.; Sundström, L.; Punttila, P. Facultative polygyny and habitat succession in boreal ants. Biol. J. Linn. Soc. 1995, 56, 533-551. [CrossRef]

14. Punttila, P. Succession, forest fragmentation, and the distribution of wood ants. Oikos 1996, 75, $291-298$. [CrossRef]

15. Savolainen, R.; Vepsäläinen, K.; Wuorenrinne, H. Ant assemblages in the tiaga biome: Testing the role of territorial wood ants. Oecologia 1989, 81, 481-486. [CrossRef] [PubMed]

16. Punttila, P.; Haila, Y.; Tukia, H. Ant communities in taiga clearcuts: Habitat effects and species interactions. Ecography 1996, 19, 16-28. [CrossRef]

17. Finnegan, R.J. Ants as predators of forest pests. Entomophaga Mem. H. S. 1974, 7, 53-59.

18. Torgersen, T.R.; Mason, R.R. Predation on egg masses of Douglas-fir tussock moth. Environ. Entomol. 1987, 16, 90-93. [CrossRef]

19. Way, M.J.; Khoo, K.C. Role of ants in pest management. Ann. Rev. Entomol. 1992, 37, 479-503. [CrossRef] 
20. Wagner, D.; Brown, M.J.F.; Gordon, D.M. Harvester ant nests, soil biota and soil chemistry. Oecologia 1997, 112, 232-236. [CrossRef] [PubMed]

21. Heithaus, E.R. Seed predation by rodents in three ant-dispersed plants. Ecology 1981, 62, 136-145. [CrossRef]

22. Brown, J.H.; Reichman, O.J.; Davidson, D.W. Granivory in desert ecosystems. Annu. Rev. Ecol. Evol. Syst. 1979, 10, 201-227. [CrossRef]

23. Haines, B.L. Element and energy flows through colonies of the leaf-cutting ant, Atta colombica, in Panama. Biotropica 1978, 10, 270-277. [CrossRef]

24. Torgersen, T.R.; Bull, E.V. Down logs as habitat for forest dwelling ants-The primary prey of pileated woodpeckers in northeastern Oregon. Northwest Sci. 1995, 69, 294-303.

25. Gyug, L.W.; Higgins, R.J.; Todd, M.A.; Meggs, J.M.; Lindgren, B.S. Dietary dependence of Williamson's Sapsucker nestlings on ants associated with dead and decaying wood in British Columbia. Can. J. For. Res. 2014, 44, 628-637. [CrossRef]

26. Noyce, K.V.; Kannowski, P.B.; Riggs, M.R. Black bears as ant-eaters: Seasonal associations between bear myrmecophagy and ant ecology in north-central Minnesota. Can. J. Zool. 1997, 75, 1671-1686. [CrossRef]

27. Elgmork, K.; Unander, S. Brown bear use of ant mounds in Scandinavia. Ursus 1999, 10, 269-274.

28. Swenson, J.E.; Jansson, A.; Riig, R.; Sandegren, F. Bears and ants: Myrmecophagy by brown bears in central Scandinavia. Can. J. Zool. 1999, 77, 551-561. [CrossRef]

29. Lindgren, B.S.; MacIsaac, A.M. A preliminary study of ant diversity and of ant dependence on dead wood in central interior British Columbia. In Proceedings of the Symposium on the Ecology and Management of Dead Wood in Western Forests, Reno, NV, USA, 2-4 November 1999; Shea, P.J., Laudenslayer, W.F., Jr., Valentine, B., Weatherspoon, C.P., Lisle, T.E., Eds.; USDA Forest Service: Albany, CA, USA, 2002; pp. 111-119.

30. Lafleur, B.; Parsons, W.F.J.; Bradley, R.L.; Francoeur, A. Ground-nesting ant assemblages and their relationships to habitat factors along a chronosequence of postfire-regenerated lichen-spruce woodland. Environ. Entomol. 2006, 35, 1515-1524.

31. Meidinger, D.V.; Pojar, J. Ecosystems of British Columbia; BC Ministry of Forests: Victoria, BC, Canada, 1991; p. 330.

32. Maser, C.; Anderson, R.G.; Cromack, K., Jr.; Williams, J.T.; Martin, R.E. Dead and down woody material. In Wildlife Habitats in Managed Forests: The Blue Mountains of Oregon and Washington; Thomas, J.W., Ed.; U.S. Department of Agriculture: Washington, DC, USA, 1979; pp. 78-95.

33. Menard, S. Applied Logistic Regression Analysis, 2nd ed.; Sage Publications Inc.: Thousand Oaks, CA, USA, 2002; p. 111.

34. Swets, J.A. Measuring the accuracy of diagnostic systems. Science 1988, 4857, 1285-1293. [CrossRef]

35. Bolton, B.; Alpert, G.; Ward, P.S.; Naskrecki, P. Bolton's Catalogue of the Ants of the World. Available online: http:/ / www.hup.harvard.edu/catalog.php?isbn=9780674021518 (accessed on 19 April 2017).

36. Wheeler, G.C.; Wheeler, J. The Ants of North Dakota; The University of North Dakota Press: Grand Forks, ND, USA, 1963; p. 326.

37. Wheeler, G.C.; Wheeler, J. The Ants of Nevada; Natural History Museum of Los Angeles County: Los Angeles, CA, USA, 1986; p. 138.

38. Francoeur, A. Révision taxonomique des espèces néarctiques du group fusca, genre Formica (Formicidae: Hymenoptera). Mém. Soc. Entomol. Québec 1973, 3, 1-316.

39. Naumann, K.; Preston, W.B.; Ayre, G.L. An annotated checklist of the ants (Hymenoptera: Formicidae) of British Columbia. J. Entomol. Soc. BC 1999, 96, 29-68.

40. Hansen, L.D.; Klotz, J.H. Carpenter Ants of The United States and Canada; Comstock Publishing Associates: Ithaca, NY, USA, 2005; p. 204.

41. Higgins, R.J.; Lindgren, B.S. Seral changes in ant (Hymenoptera: Formicidae) assemblages in the sub-boreal forests of British Columbia. Insect Conserv. Divers. 2015, 8, 337-347. [CrossRef]

42. Kéry, M.; Schmidt, B.R. Imperfect detection and its consequences for conservation. Community Ecol. 2008, 9, 207-216. [CrossRef]

43. Hölldobler, B.; Wilson, E.O. The Ants; The Belknap Press of Harvard University Press: Cambridge, MA, USA, 1990; p. 732.

44. Higgins, R.J.; Lindgren, B.S. The effect of manipulated shading on the colony abundance of two species of ants, Formica aserva and Leptothorax muscorum, in dead wood. Entomol. Exp. Appl. 2012, 143, 292-300. [CrossRef] 
45. Shane, C.F.; Steyaert, S.M.J.G.; Swenson, J.E.; Storch, I.; Kindberg, J.; Barck, H.; Zedrosser, A. A “clearcut" case? Brown bear selection of coarse woody debris and carpenter ants on clearcuts. For. Ecol. Manag. 2015, 348, 164-173.

46. Savolainen, R.; Seppä, P. Genetic relatedness among worker nestmates of three formicine slave-making ants. Insect Soc. 1996, 43, 31-36. [CrossRef]

47. Francoeur, A. The ant fauna near the tree-line in northern Quebec. Nordicana 1983, 47, 177-180.

48. Billeck, I. Density dependence and colony growth in the ant species Formica neorufibarbis. J. Anim. Ecol. 2001, 70, 895-905. [CrossRef]

49. Billeck, I. Worker demography in the ant Formica neorufibarbis. Ecol. Entomol. 2003, 28, 139-144. [CrossRef]

50. Elmes, G.W.; Keller, L. Distribution and Ecology of Queen Numbers in Ants of the Genus Myrmica. In Queen Number and Sociality in Insects; Keller, L., Ed.; Oxford University Press: Oxford, UK, 1993; pp. $294-307$.

51. Heinze, J. Habitat structure, dispersal strategies and queen number in two boreal Leptothorax species. Oecologia 1993, 96, 32-39. [CrossRef] [PubMed]

52. Heinze, J.; Stahl, M.; Hölldobler, B. Ecophysiology of hibernation in boreal Leptothorax ants (Hymenoptera: Formicidae). Ecoscience 1996, 3, 429-435. [CrossRef]

53. Stille, M. Queen/worker thorax volume ratios and nest-founding strategies in ants. Oecologia 1996, 105, 87-93. [CrossRef] [PubMed]

54. Rosengren, R.; Sundström, L.; Fortelius, W. Monogyny and polygyny in Formica ants: The result of alternative dispersal tactics. In Queen Number and Sociality in Insects; Keller, L., Ed.; Oxford University Press: Oxford, UK, 1993; pp. 308-333.

55. Cherix, D.; Chautems, D.; Fletcher, D.J.C.; Fortelius, W.; Gris, G.; Keller, L.; Passera, L.; Rosengren, R.; Vargo, E.L.; Walter, F. Alternative reproductive strategies in Formica lugubris Zett. Ethol. Ecol. Evol. 1991, 1, 61-66.

56. Heinze, J.; Hölldobler, B. Ants in the cold. Memorabilia Zool. 1994, 48, 99-108.

57. Akre, R.D.; Hansen, L.D.; Myhre, E.A. Colony size and polygyny in carpenter ants (Hymenoptera: Formicidae). J. Kans. Entomol. Soc. 1994, 67, 1-9.

58. Wilson, E.O.; Hunt, G.L.J. Habitat selection by the queens of two field-dwelling species of ants. Ecology 1966, 47, 485-487. [CrossRef]

59. Punttila, P.; Autio, O.; Kotiaho, J.S.; Kotze, D.J.; Loukola, O.J.; Noreika, N.; Vuori, A.; Vepsäläinen, K. The effects of drainage and restoration of pine mires on habitat structure, vegetation and ants. Silva. Fennica. 2016, 50, 1462. [CrossRef]

60. Savolainen, R.; Vepsäläinen, K. A competition hierarchy among boreal ants: Impact on resource partitioning and community structure. Oikos 1988, 51, 135-155. [CrossRef]

61. Cerdá, X.; Retana, J.; Cros, S. Thermal disruption of transitive hierarchies in Mediterranean ant communities. J. Anim. Ecol. 1997, 66, 363-374. [CrossRef]

62. Jonsell, M.; Weslien, J.; Ehnström, B. Substrate requirements of red-listed saproxylic invertebrates in Sweden. Biodivers. Conserv. 1998, 7, 749-764. [CrossRef]

63. Warren, R.J.; Bradford, M.A. Ant colonization and coarse woody debris decomposition in temperate forests. Insect Soc. 2012, 59, 215-221. [CrossRef]

(C) 2017 by the authors. Licensee MDPI, Basel, Switzerland. This article is an open access article distributed under the terms and conditions of the Creative Commons Attribution (CC BY) license (http://creativecommons.org/licenses/by/4.0/). 